\title{
Dictionary of Ethiopian Biography
}

The Institute of Ethiopian Studies of Haile Selassie University is currently engaged in the preparation of a Dictionary of Ethiopian Biography to include biographies, with bibliographical references, on important personalities in Ethiopian history, in all walks of life. The Dictionary, which is edited by Dr. Richard Pankhurst, S. Chojnacki, and Innes Marshall, excludes living personalities but includes significant foreigners in Ethiopian history, and is expected to have around 4,000 or 5,000 entries which are being written by the leading scholars in their respective fields.

\section{'Orita: Ibadan Journal of Religious Studies'}

Orita: Ibadan Journal of Religious Studies, is published twice yearly in June and December by the Department of Religious Studies at the University of Ibadan. The editor is Mr. P. R. McKenzie, and Professor E. Bolaji Idowu is Chairman of the Editorial Committee. Its aim is to promote the study and understanding of religion in general and in Africa in particular and every effort will be made to give an equal coverage to African traditional religion, Christianity and Islam. The Yoruba term 'Orita' means 'where three ways meet' and articles related to the interaction of the three religions will be encouraged. The phenonemon of secularization will also be considered. Subscriptions (single copies ss.; yearly subscriptions ros. including postage) should be sent to Orita, Department of Religious Studies, University of Ibadan, Ibadan, Nigeria.

\section{'The New Africans'}

The Nen Africans: $A$ Guide to the Contemporary History of Emergent Africa and its Leaders (Paul Hamlyn, London, price 45s., 504 pages) has been provided by fifty correspondents of Reuter's News Agency and edited by Sidney Taylor. A short general introduction is followed by sections on African countries arranged in alphabetical order. Each section contains a map, a concise account and history of the country and short biographies, the majority illustrated by photographs, of Africans who have played an important part in the achievement of independence. There is an index to the bibliographies.

\section{'African Adult Education'}

THE first issue of African Adult Education, the Journal of the Adult Education Association of East and Central Africa, appeared in June 1967, and it will be published twice yearly for the association by the Pergamon Press, Oxford. The journal was established as a result of the meetings of adult educationists held at Dar es Salaam in 1964 , Lusaka in 1969 , and Nairobi in $196 \%$, when it became evident that a means of communication between the ten countries belonging to the association was urgently needed.

The aim of African Adult Education is 'to serve all, who as part of their job or as part of their spare-time activity, pass on knowledge and skills to adults', and to be 'both a record of activities and a forum for the discussion of ideas, however controversial, relating to adult education in Africa'. Comments, correspondence, articles (not normally exceeding 2,000 words) and books for review as well as reviews of useful books will be welcomed by the editor, Mr. Hans Noak, P.O. Box I34I, Lusaka, Zambia. The annual subscription to non-members of the association is $£_{2}(\$ 6)$; membership is open to institutions and to individuals on payment of the sum of $£$ S (\$14) and IOS. (\$1.50), respectively. Subscription inquiries should be addressed to: Subscriptions Manager, Headington Hill Hall, Oxford. 